\title{
Kepemimpinan Kepala Sekolah Dalam Meningkatkan Kualitas Pendidikan di SMP Islam Darul Karomah Mandaranrejo Pasuruan
}

\author{
M. Ma'ruf, S.S.,M.Pd.I \\ Dosen STIT PGRI Pasuruan \\ Email; ahmadm4ruf@gmail.com
}

\section{ABSTRAK}

Kepemimpinan adalah proses kegiatan seseorang yang memiliki kemampuan untuk mendorong, mempengaruhi, mengarahkan, dan menggerakkan individu-individu supaya timbul kerjasama secara teratur dalam upaya mencapai tujuan yang telah ditetapkan bersama, kualitas pendidikan adalah sebagai usaha manusia untuk menumbuhkan dan mengembangkan potensi-potensi pembawaan baik jasmani maupun rohani sesuai dengan nilai-nilai dalam masyarakat dan kebudayaan, untuk itulah maka pendidikan harus benar-benar memiliki kualitas bagi manusia. Pemimpin pendidikan dalam hal ini adalah Kepala Sekolah sebagai orang yang bertanggung jawab terhadap pelaksanaan pendidikan dan pengajaran di lembaga pendidikan, harus memiliki kesiapan dan kemampuan untuk membangkitkan semangat kerja personal. Penelitian ini dilakukan mencari sistem kepemimpinan kepala sekolah dalam meningkatkan kualitas pendidikan di SMP Islam Darul Karomah Mandaranrejo Pasuruan.

Penelitian ini menggunakan pendekatan kualitatif dengan jenis penelitian berupa studi kasus di SMP Islam Darul Karomah Mandaranrejo Pasuruan. Pengumpulan data diambil dari wawancara, observasi dan dokumentasi yang semuanya dikumpulkan dan dianalisis untuk menjawab permasalahan penelitian yang diajukan peneliti dalam fokus penelitian. Adapun informan penelitian ini adalah Kepala Sekolah, Wakil Kepala sekolah bidang kurikulum, wakil kepala sekolah bidang kesiswaan, wakil kepala sekolah bidang sarana \& prasarana dan guru di SMP Islam Darul Karomah.

Dalam penelitian tentang kepemimpinan kepala sekolah dalam meningkatkan kualitas pendidikan di SMP Islam Darul Karomah Mandaranrejo Pasuruan. Peneliti menemukan bahwa Kepala Sekolah memegang peranan yang sangat penting dalam upaya peningkatan kualitas pendidikan Islam di SMP Islam Darul Karomah. Tipe kepemimpinan yang 
dikembangkan Kepala Sekolah SMP Islam Darul Karomah selalu berupaya untuk terus melakukan peningkatan kualitas pendidikan dengan memposisikan dirinya sesuai dengan perannya yaitu sebagai administrator dan supervisor. Adapun usaha Kepala Sekolah dalam meningkatkan kualitas pendidikan di SMP Islam Darul Karomah antara lain dengan mengadakan full day school, mengadakan program remedial khusus, membangun gedung tingkat dua, membuat lapangan basket, meningkatkan kualitas guru, menambah mata pelajaran khusus, dan pembiasaan sholat berjamaah. Sedangkan sebagai administrator Kepala Sekolah berusaha untuk mengelola dan mengawasi bidang administrasi kesiswaan, pengajaran, kepegawaian, keuangan serta sarana dan prasarana dengan sebaik-baiknya. Adapun sebagai supervisor kepala Sekolah berusaha membantu memberi supervisi kepada stafnya dalam menyusun program, mempertinggi kecakapan dan ketrampilan mengajar, serta mengadakan evaluasi secara kontinyu.

Kata Kunci : Kepemimpinan Kepala Sekolah, Kualitas Pendidikan

\section{A. PENDAHULUAN}

\section{Konteks Penelitian}

Seorang pemimpin mempunyai tanggung jawab yang berat.Mengingatperannya yang sangat besar, keuletannya serta kewibawaannya dalam membuat langkah-langkah baru sebagai jawaban dari kebutuhan masyarakat. Hal ini sebagaimana ditulis oleh Bernard Kutner, yang dikutip oleh Evendy $M$. Siregar tentang kepemimpinan:Dalam kepemimpinan tidak ada asas yang universal, yang nampak ialah proses kepemimpinan dan pola hubungan antar pemimpinnya. Fungsi utama kepemimpinan terletak dalam jenis khusus dari perwakilan (group representation). Seorang pemimpin harus mewakili kelompoknya sendiri. Mewakili kelompoknya mengandung arti bahwa si pemimpin mewakili fungsi administrasi secara eksekutif. Ini meliputi koordinasi dan integrasi berbagai aktivitas, kristalisasi kebijaksanaan kelompok dan penilaian terhadap macam peristiwa yang baru terjadi dan membawakan fungsi kelompok. Selain itu seorang

43| Kepemimpinan Kepala Sekolah Dalam Meningkatkan Kualitas PendidikanDi Smp Islam Darul Karomah Mandaranrejo Pasuruan 
pemimpin juga merupakan perantara dari orang dalam kelompoknya di luar kelompoknya. ${ }^{1}$

Berkenaan dengan kepemimpinan ini. Dirawat mengemukakan dalam bukunya "Pengantar Kepemimpinan Pendidikan" bahwa kepemimpinan adalah merupakan suatu kemampuan dan proses mempengaruhi, mengkoordinir, dan mengendalikan orang lain yang ada hubungannya dengan pengembangan ilmu pengetahuan atau pendidikan serta agar kegiatan yang dilaksanakan lebih efisien dan efektif dalam pencapaian tujuan-tujuan pendidikan dan pengajaran. ${ }^{2}$

Dari kutipan tersebut dapat diambil suatu pengertian, bahwa untuk mewujudkan program pelaksanaan pendidikan yang direncanakan, maka dalam pelaksanaannya diperlukan seseorang yang dapat mempengaruhi, mendorong serta menggerakkan komponen-komponen yang ada dalam lembaga pendidikan yang dapat mengarahkan pada pencapaian tujuan pendidikan pada suatu lembaga pendidikan. Menjadi seorang pemimpin pendidikan, tidak saja dituntut untuk menguasai teori kepemimpinan, akan tetapi ia juga harus terampil dalam menerapkan situasi praktis di lapangan kerja dan etos kerja yang tinggi untuk membawa lembaga pendidikan yang dipimpinnya. Pemimpin pendidikan dalam hal ini adalah Kepala Sekolah sebagai orang yang bertanggung jawab terhadap pelaksanaan pendidikan danpengajaran di lembaga pendidikan, harus memiliki kesiapan dan kemampuan untuk membangkitkan semangat kerja personal. Seorang pemimpin juga harus mampu menciptakan iklim dan suasana yang kondusif, aman, nyaman, tentram, menyenangkan, dan penuh semangat dalam bekerja bagi para pekerja dan para pelajar. Sehingga pelaksanaan pendidikan dan pengajaran dapat berjalan tertib dan lancar dalam mencapai tujuan yang diharapkan. Hal ini sebagaimana dituturkan oleh Hendyat Soetopo dalam bukunya "Pengantar Operasional Administrasi Pendidikan", bahwa Kepemimpinan pendidikan adalah suatu kemampuan dan proses mempengaruhi, membimbing, mengkoordinir, dan menggerakkan orang lain yang ada hubungannya dengan pengembangan ilmu pendidikan serta pengajaran

\footnotetext{
${ }^{1}$ Kurtner, Bernard. 1989. Bagaimana Menjadi Pemimpin Yang Berhasil. Jakarta : PD. Mari Belajar, hlm. 152

${ }^{2}$ Kurtner, Bernard. 1989. Bagaimana Menjadi Pemimpin Yang Berhasil....hlm. 33 
supaya aktivitas-aktivitas yang dijalankan dapat lebih efektif dan efisien dalam pencapaian tujuan pendidikan dan pengajaran. ${ }^{3}$

Pendidikan apabila dipahami dari segi agama memiliki nilai yang sangat strategis. Sebagaimana ketika Rasulullah SAW berdakwah mengajarkan wahyu yang pertama kali turun, beliau berkonsentrasi kepada kemampuan baca tulis, hal ini sebagaimana terdapat dalam surat Al-Alaq ayat1-5:

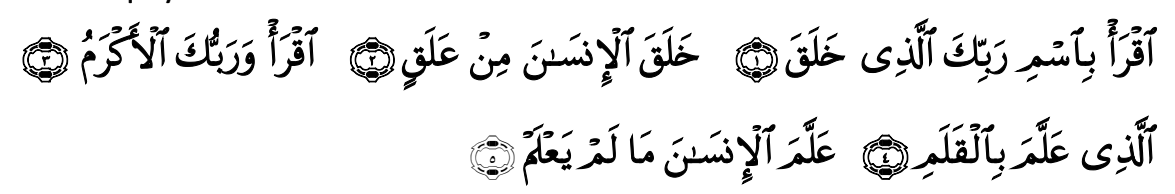

"Bacalah dengan (menyebut) nama Tuhanmu Yang menciptakan, Dia telah menciptakan manusia dari segumpal darah. Bacalah, dan Tuhanmulah Yang Maha Pemurah, Yang mengajar (manusia) dengan perantaran kalam, Dia mengajar kepada manusia apa yang tidak diketahuinya." ${ }^{4}$

Dari ayat tersebut mengandung ajakan/anjuran bahwa menjadi manusia itu harus mengerti, cerdas dan mempunyai wawasan masa depan, sehingga mereka akan terbebas dari segala bentuk penindasan, perbudakan, dan pembodohan yang sifatnya dapat merusak kehormatan manusia. Berdasarkan doktrin inilah yang kemudian mengilhami para pemimpin untuk mampu menjadi pemimpin yang disegani dan diharapkan banyak orang dalam menegakkan syariat Islam. Agar tujuan pendidikan dapat terlaksana dengan baik, maka diperlukan pemimpin yang mengerti akan komitmen yang menjadi tujuan tersebut. Karena pendidikan mengandung nilai-nilai yang besar dalam kehidupan manusia baik di dunia maupun di akherat yaitu nilai-nilai ideal Islam. Dalam hal ini ada 3 kategori, yaitu dimensi yang mendorong manusia untuk memanfaatkan dunia agar menjadi bekal bagi kehidupan akherat, dimensi yang mengandung nilai yang mendorong manusia berusaha keras untuk meraih kehidupan akherat yang membahagiakan, dimensi

3 Soemanto,Wasty dan Soetopo, Hendyat. 1982. Kepemimpinan dalam Pendidikan.Surabaya : Usaha Nasional, hlm. 271

${ }^{4}$ Depag RI. Al-Qur'an dan Terjemah. Semarang: Toha Putra, hlm. 479

45 | Kepemimpinan Kepala Sekolah Dalam Meningkatkan Kualitas

PendidikanDi Smp Islam Darul Karomah Mandaranrejo Pasuruan 
yang mengandung nilai yang dapat memadukan antara kehidupan duniawi dan ukhrowi. ${ }^{5}$

Disamping itu, peningkatan kualitas pendidikan bukanlah suatu hal yang mudah untuk diwujudkan. Karena banyaknya faktor-faktor yang mempengaruhinya yang tanpa ada usaha utnuk meperhatikan dan mencari solusi, maka usaha peningkatan kualitas pendidikan mustahil akan terwujud. Realitanya, banyak lembaga pendidikan yang dapat tumbuh dan berkembang menjadi lebih baik dan ada pula yang mengalami kemandekan dan bahkan tinggal menunggu kehancurannya. Adapun salah satu faktor penyebabnya adalah terletak pada kompetensi dan kepemimpinan Kepala Sekolah dalam memenej Sekolah.

Peneliti berasumsi bahwa masalah-maslah dalam pendidikan itu dapat diminimalisir jika kepala sekolah mampu memimpin secara profesional. Maka dari itu, dalam penelitian ini, peneliti mengambil tema "Kepemimpinan Kepala Sekolah Dalam Meningkatkan kualitas Pendidikandi SMP Islam Darul Karomah Mandaranrejo Pasuruan".

\section{Fokus Penelitian}

Setelah pemaparan konteks penelitian sebagaimana yang telah dikemukakan sebelumnya, maka peneliti merumuskan fokus penelitian (research focus) sebagai berikut:

a. Bagaimana kepemimpinan Kepala Sekolah di SMP Islam Darul Karomah Mandaranrejo Pasuruan ?

b. Bagaimana upaya Kepala Sekolah dalam meningkatkan kualitas pendidikan di SMP Islam Darul Karomah Mandaranrejo Pasuruan?

c. Bagaimana peran Kepala Sekolah dalam Meningkatkan kualitas pendidikan di SMP Islam Darul Karomah Mandaranrejo Pasuruan ?

\section{Tujuan Penelitian}

Secara substansial tujuan dari penelitian adalah menyelesaikan masalah-masalah yang telah dirumuskan sebelumnya. Maka dari perumusan itulah akan terdapat sesuatu yang menjadi rumusan dari hasil sebuah penelitian. Adapun secara terperinci, tujuan penelitian ini dimaksudkan untuk;

a. Mendiskripsikan dan menganalisis model kepemimpinan Kepala Sekolah di SMP Islam Darul Karomah Mandaranrejo Pasuruan

${ }^{5}$ Indar, Djumberansjah. 1992. Ilmu Pendidikan Islam. Malang.: IAIN Sunan Ampel, hlm. 23-24

M. Ma'ruf | 46 
b. Mendiskripsikan dan menganalisis upaya Kepala Sekolah dalam meningkatkan kualitas pendidikan di SMP Islam Darul Karomah Mandaranrejo Pasuruan.

c. Mendiskripsikan dan menganalisis peran Kepala Sekolah dalam Meningkatkan kualitas pendidikan di SMP Islam Darul Karomah Mandaranrejo Pasuruan.

\section{Manfaat Penelitian}

Kegunaan yang dapat diambil dari hasil penelitian ini diantaranya adalah:

a. Manfaat Teoritis

Hasil penelitian dapat menambah khazanah keilmuan dan wawasan pengetahuan dalam bidang pendidikan dan sosial masyarakat dan diharapakan mampu memberikan kontribusi positif terhadap peningkatan kualitas pendidikan.

b. Manfaat Praktis

Dari hasil penelitian ini, berguna juga bagi kepala sekolah atau pimpinan lembaga pendidikan Islam sebagai acuan pertimbangan dalam usaha meningkatkan kualitas pendidikan yang dipimpinnya. Hasil penelitian ini memungkinkan adanya tindak lanjut yang mendalam dalam pengembangan kualitas pendidikan di SMP Islam Darul Karomah Mandaranrejo Pasuruan.

\section{B. KAIIAN PUSTAKA}

\section{Pengertian Kepemimpinan Pendidikan}

Istilah "Kepemimpinan Pendidikan" mengandung dua pengertian. Dimana kata "pendidikan" menerangkan dalam lapangan apa dan dimana kepemimpinan itu berlangsung, dan sekaligus menjelaskan pula sifat atau ciri-ciri bagaimana yang harus terdapat atau dimiliki oleh kepemimpinan tersebut.

Pengertian "Kepemimpinan" itu bersifat universal, berlaku dan terdapat pada berbagai bidang kegiatan hidup manusia. Oleh karena itu. Sebelum dibahas pengertian kepemimpinan yang menjurus pada bidang pendidikan, maka perlu dipahami dahulu pengertian kepemimpinan yang bersifat universal. Dalam hal ini banyak sekali para ahli yang berusaha memberikan definisi kepemimpinan, diantaranya :

47| Kepemimpinan Kepala Sekolah Dalam Meningkatkan Kualitas

PendidikanDi Smp Islam Darul Karomah Mandaranrejo Pasuruan 
a. Menurut Drs. Dirawat,Busro Lamberi, Soekarto Indra Fachrudi dalam bukunya "Pengantar KepemimpinanPendidikan" bahwa :

Kepemimpinan adalah kemampuan dan kesiapan yang dimiliki oleh seseorang untuk dapat mempengaruhi, mendorong, mengajak, menuntun, menggerakkan dan kalau perlu memaksa orang lain, agar ia menerima pengaruh itu dan selanjutnya berbuat sesuatu yang dapat membantu pencapaian sesuatu maksud atau tujuan-tujuan tertentu. ${ }^{6}$

b. Menurut Dr.Hadari Nawawi dalam bukunya "Administrasi Pendidikan", bahwa :

Kepemimpinan berarti kemampuan menggerakkan memberikan motivasi dan mempengaruhi orang-orang agar bersedia melakukan tindakan-tindakan yang terarah pada pencapaian tujuan melalui keberanian mengambil keputusan tentang kegiatan yang harus dilakukan. $^{7}$

c. Menurut Burhanuddin dalam bukunya "Analisis Administrasi Manajemen Dan Kepemimpinan Pendidikan", bahwa : Kepemimpinan adalah usaha yang dilakukan oleh seseorang dengan segenap kemampuan yang dimilikinya untuk mempengaruhi, mendorong, mengarahkan dan menggerakkan individu-individu supaya mereka mau bekerja dengan penuh semangat dan kepercayaan dalam mencapai tujuan-tujuan organisasi ${ }^{8}$.

Dari ketiga definisi diatas, dapat disimpulkan bahwa kepemimpinan adalah proses kegiatan seseorang yang memiliki kemampuan untuk mempengaruhi, mendorong, mengarahkan, dan menggerakkan individu-individu supaya timbul kerjasama secara teratur dalam upaya mencapai tujuan yang telah ditetapkan bersama. Sedangkan pengertian pendidikan itu sendiri, sebagaimana yang dikatakan oleh Burhanuddin dalam bukunya "Analisis Administrasi Manajemen dan Kepemimpinan Pendidikan", bahwa : Pendidikan merupakan suatu usaha atau proses yang dilakukan secara sadar oleh

${ }^{6}$ Dirawat, Lamberi, Busro, Indra Fachrudi, Soekarto.1983. Pengantar Kepemimpinan Pendidikan. Surabaya : Usaha Nasional, hlm. 43

${ }^{7}$ Nawawi, Hadari. 1988. Administrasi Pendidikan. Jakarta : CV Haji Masagung, hlm. 81

${ }^{8}$ Burhanuddin. 1994. Analisis Administrasi Manajemen Dan Kepemimpinan Pendidikan. Jakarta: Bumi Aksara, hlm. 63

M. Ma'ruf | 48 
orang dewasa untuk mendidik dan mengajar anak didik agar mereka dapat mencapai kedewasaan. ${ }^{9}$

Apabila pengertian kepemimpinan dipadukan dengan pengertian pendidikan, maka akan muncul pengertian Kepemimpinan pendidikan sebagai satu kemampuan dan proses mempengaruhi, mengkoordinir, dan menggerakkan orang lain yang ada hubungan dengan pengembangan ilmu pendidikan dan pelaksanaan pendidikan dan pengajaran, agar kegiatan-kegiatan yang dijalankan dapat lebih efisien dan efektif didalam pencapaian tujuan-tujuan pendidikan dan pengajaran. ${ }^{10}$

Dari pengertian kepemimpinan pendidikan di atas, diketahui terdapat beberapa unsur pokok, diantaranya :

1. Tujuan kepemimpinan

2. Individu yang mempengaruhi kelompok/organisasi/lembaga (pemimpin)

3. Individu-individu yang dipengaruhi, dikoordinasi, digerakkan (yang dipimpin)

4. Proses interaksi antara pemimpin dan yang dipimpin dalam rangka mempengaruhi, mengkoordinasikan dan menggerakkan.

5. Situasi berlangsungnya kepemimpinan.

\section{Syarat-syarat Kepribadian Pemimpin}

Sebagai seseorang pemimpin, tentu saja diharapkan memiliki kelebihan-kelebihan daripada orang yang dipimpinnya.Oleh karena pemimpin pendidikan nantinya selalu berhadapan dengan orang lain dalam konteks sosial, maka ia harus memiliki syarat kepribadian tertentu. Syarat-syarat tersebut antara lain sebagaimana yang dikemukakan oleh Hadari Nawawi di bawah ini: ${ }^{11}$

a) Memiliki kecerdasan atau intelegensi yang baik

b) Percaya diri sendiri dan bersifat membership

\footnotetext{
${ }^{9}$ Burhanuddin. 1994. Analisis Administrasi Manajemen Dan Kepemimpinan Pendidikan..., hlm. 64

${ }^{10}$ Soemanto,Wasty dan Soetopo, Hendyat. 1984. Kepemimpinan Dan Supervisi Pendidikan. Jakarta : PT. Bina Aksara, hlm. 4

${ }^{11}$ Nawawi, Hadari. 1988. Administrasi Pendidikan. Jakarta : CV Haji Masagung, hlm. 84-90

49|Kepemimpinan Kepala Sekolah Dalam Meningkatkan Kualitas

PendidikanDi Smp Islam Darul Karomah Mandaranrejo Pasuruan
} 
c) Cakap bergaul dan ramah tamah

d) Kreatif, penuh inisiatif dan memiliki hasrat/kemauan untuk maju dan berkembang menjadi lebih baik.

e) Organisatoris yang berpengaruh dan berwibawa.

f) Memiliki keahlian atau ketrampilan dalam bidangnya.

g) Suka menolong, memberi petunjuk dapat menghukum secara konsekuen dan bijaksana

h) Memiliki keseimbangan/kestabilan emosional dan bersifat sabar

i) Memiliki semangat pengabdian dan kesetiaan yang tinggi

j) Berani mengambil keputusan dan bertanggungjawab.

k) Jujur, rendah hati, sederhana dan dapat dipercaya.

I) Bijaksana dan selalu berlaku adil.

m) Disiplin

n) Berpengetahuan dan berpandangan luas.

o) Sehat jasmani dan rohani.

Sedangkan menurut Burhanuddin, syarat-syarat kepribadian yang harus dimiliki oleh seorang pemimpin adalah :

a. Personality, yang mana melalui sifat-sifat kepribadian tersebut, seseorang dapat memperoleh pengakuan dari orang lain sekaligus menjadi penentu bagi kepemimpinannya.

b. Purposes, yaitu seorang Kepala Sekolah harus benar-benar memahami tujuan pendidikan itu sendiri secara jelas.

c. Knowledge, yaitu suatu kelompok akan menaruh kepercayaan pada sang pemimpin, apabila mereka menyadari bahwa otoritas kepemimpinannya dilengkapi dengan skop pengetahuan yang luas dan mampu memberikan keputusan yang mantap.

d. Profesional skill, yaitu Kepala Sekolah harus memiliki ketrampilanketrampilan profesional yang efektif dalam fungsi-fungsi administrasi pendidikan. ${ }^{12}$

Bila semua prasyarat kepribadian sebagaimana tersebut diatas dimiliki oleh seorang pemimpin, maka ia akan dapat menjalankan kepemimpinannya dengan baik. Oleh karena itu, setiap pemimpin pendidikan hendaknya berusaha memiliki sifat-sifat kepribadian tersebut.

${ }^{12}$ Burhanuddin. 1994. Analisis Administrasi Manajemen Dan Kepemimpinan Pendidikan. Jakarta: Bumi Aksara, hlm. 78-80 


\section{Tipe-tipe Kepemimpinan}

Dalam menjalankan tugasnya sebagai pemimpin, yaitu menggerakkan atau memberi motivasi orang lain agar melakukan tindakan-tindakan yang selalu terarah pada pencapaian tujuan organisasi, berbagai cara dapat dilakukan oleh seseorang pemimpin. Cara itu mencerminkan sikap dan pandangan pemimpin terhadap orang yang dipimpinnya. Yang memberikan gambaran pula tentang bentuk (tipe) kepemimpinannya yang dijalankannya. Adapun tipe-tipe kepemimpinan pendidikan yang pokok itu ada tiga yaitu otokratis, laissez faire, dan demokratis. ${ }^{13}$

Sedangkan menurut Hendyat Soetopo dan Wasty Soemanto, kepemimpinan pendidikan dapat diklasifikasikan menjadi 4 tipe kepemimpinan yaitu: (1) Tipe Otoriter/Otokrasi, (2) Tipe Laissez faire, (3) Tipe Demokratis, (4) Tipe Diktator. ${ }^{14}$

Untuk lebih jelasnya, penulis akan diuraikan masing-masing dari tipe kepemimpinan tersebut.

a) Tipe Otokratis

Otokratis berasal dari kata oto yang berarti sendiri, dan kratos yang berarti pemerintah. Jadi otokratis berarti mempunyai sifat memerintah dan menentukan sendiri. ${ }^{15}$

b) Tipe Laissez faire

Laissez faire jika diterjemahkan dapat diartikan sebagai "biarkan saja berjalan" atau 'tidak usah dihiraukan', jadi mengandung sikap 'masa bodo'. 16

c). Tipe Demokratis

Kepemimpinan demokratis adalah kepemimpinan yang aktif ,dinamis, dan terarah yang berusaha memanfaatkan setiap orang untuk kepentingan kemajuan dan perkembangan organisasi. Saransaran, pendapat-pendapat dan kritik-kritik setiap anggota disalurkan dengan sebaik-baiknya dan diusahakan

13 Purwanto, M. Ngalim, dan Djojopranoto, Sutaji. 1991. Administrasi Pendidikan. Jakarta : Mutiara Sumber Wdya, hlm. 46

14 Soemanto,Wasty dan Soetopo, Hendyat. 1984. Kepemimpinan Dan Supervisi Pendidikan. Jakarta : PT. Bina Aksara, hlm. 284

${ }^{15}$ Rifa'i, M.Moh. 1986. Administrasi Pendidikan. Bandung. Jenmars, hlm. 38

${ }^{16}$ ibid hlm. 41

51 | Kepemimpinan Kepala Sekolah Dalam Meningkatkan Kualitas

PendidikanDi Smp Islam Darul Karomah Mandaranrejo Pasuruan 
memanfaatkannya bagi pertumbuhan dan kemajuan organisasi sebagai perwujudan tanggung jawab bersama. ${ }^{17}$

Tipe kepemimpinan demokratis ini memang paling sesuai dengan konsep Islam Yang mana di dalamnya banyak menekankan prinsip musyawarah untuk mufakat. Hal ini sebagaimana terdapat dalam surah Ali Imron ayat 159, yang berbunyi:

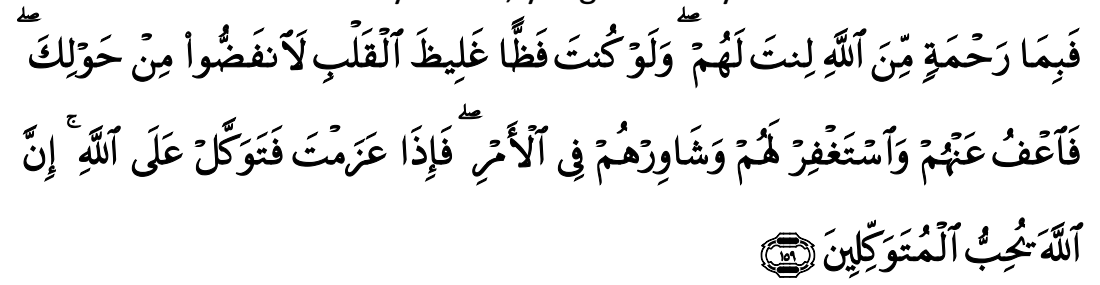

Artinya :"Maka disebabkan rahmat dari Allah-lah kamu berlaku lemah lembut terhadap mereka.sekiranya kamu bersikap keras lagi berhati kasar, tentulah mereka menjauhkan diri dari sekelilingmu. Karena itu ma'afkanlah mereka, mohonkanlah ampun bagi mereka, dan bermusyawaratlah dengan mereka dalam urusan itu. Kemudian apabila kamu Telah membulatkan tekad, Maka bertawakkallah kepada Allah. Sesungguhnya Allah menyukai orang-orang yang bertawakkal kepada-Nya"(Q.S Ali Imron (2): 159).

d) Tipe Pseudo Demokatis

Pseudo berarti palsu, pura-pura. Pemimpin semacam ini berusaha memberikan kesan dalam penampilannya seolah-olah dia demokratis, sedangkan maksudnya adalah otokrasi, mendesakkan keinginannya secara halus. ${ }^{18}$

Jadi, pemimpin pseudo demokratis sebenarnya adalah orang otokratis, tetapi pandai menutup-nutupi sifatnya dengan penampilan yang memberikan kesan seolah-olah ia demokratis.

Sedangkan menurut Sondang P. Siagian, tipe pemimpin itu dapat digolongkan menjadi lima, yaitu: (1) Tipe Otokrasi, (2) Tipe Militeristis, yaitu senang pada formalitas yang berlebihlebihan,menuntut disiplin yang tinggi dan kaku dari bawahan serta

\footnotetext{
${ }^{17}$ Soemanto, Wasty dan Soetopo, Hendyat. 1984. Kepemimpinan Dan Supervisi Pendidikan..., hlm. 284

${ }^{18}$ Rifa'i, M.Moh. 1986. Administrasi Pendidikan. Bandung: Jenmars, hlm. 39
} 
sukar untuk menerima kritikan, (3) Tipe Paternalistik, yaitu pemimpin bersikap terlalu melindungi, jarangmemberikan kesempatan kepada bawahan untuk mengambil inisiatif dan mengambil keputusan serta bersikap maha tahu, (4) Tipe Kharismatik, yaitu pemimpin yang diterima karena kepribadiannya yang berpengaruh dan dipercayai sehingga diikuti pendapat dan keputusannya, (5) Tipe Demokratis. ${ }^{19}$

Secara implisit tergambar bahwa untuk menjadi pemimpin tipe demokratis bukanlah suatu hal yang mudah untuk dicapai.Akan tetapi karena pemimpin yang demikianlah yang paling ideal, alangkah baiknya jika semua pemimpin berusaha menjadi seorang pemimpin yang demokratis.

\section{Faktor-faktor Yang Mempengaruhi Kepemimpinan}

Dalam menjalankan tugas kepemimpinannya, seseorang yang menduduki profesi sebagai pemimpin pendidikan dipengaruhi oleh faktor-faktor yang mewarnai pola kepemimpinannya. Hal ini sebagaimana yang dikemukakan oleh Hendyat Soetopo dan Wasty Soemanto, sebagai berikut:

a. Faktor-faktor legal yang berpengaruh dalam kependidikan.

b. Kondisi sosial ekonomi dan konsep-konsep pendidikan sebagai pengaruh dalam kepemimpinan.

c. Hakekat dan atau ciri sekolah sebagai pengaruh kepemimpinan.

d. Kepribadian pemimpin pandidikan dan latihan-latihan sebagai faktor yang mempengaruhi kepemimpinan.

e. Perubahan-perubahan yang terjadi dalam teori pendidikan sebagai faktor yang mempengaruhi kepemimpinan. ${ }^{20}$

Disamping itu pula, M. Ngalim Purwanto juga mengemukakan adanya faktor-faktor yang pada umumnya sangat dominan mempengaruhi perilaku seorang pemimpin, diantaranya:

\footnotetext{
${ }^{19}$ Siagian, Sondang P. 1989. Filsafat Administrasi. Jakarta : CV Haji Masagung, hlm. 41

${ }^{20}$ Soemanto,Wasty dan Soetopo, Hendyat. 1984. Kepemimpinan Dan Supervisi Pendidikan. Jakarta : PT. Bina Aksara, hlm. 16

53|Kepemimpinan Kepala Sekolah Dalam Meningkatkan Kualitas PendidikanDi Smp Islam Darul Karomah Mandaranrejo Pasuruan
} 
a. Keahlian dan kemampuan yang dimiliki oleh pemimpin untuk menjalankan kepemimpinannya.

b. Jenis pekerjaan atau lembaga tempat pemimpin itu melaksakan tugas jabatannya.

c. Sifat-sifat kepribadian pemimpin.

d. Sifat-sifat kepribadian pengikut atau kelompok yang dipimpinnya.

e. Sangsi-sangsi yang ada di tangan pemimpin. ${ }^{21}$

Untuk lebih jelasnya, akan penulis uraikan satu-persatu mengenai faktor-faktor yang mempengaruhi kepemimpinan pendidikan, sebagai berikut:

a. Keahlian dan Pengetahuan yang dimiliki oleh pemimpin untuk menjalankan kepemimpinannya.

b. Jenis pekerjaan atau lembaga tempat pemimpin itu melaksanakan tugas jabatannya.

c. Sifat-sifat kepribadian pemimpin.

d. Sifat-sifat kepribadian pengikut atau kelompok yang dipimpinnya.

Tentang sifat-sifat kepengikutan, M. Ngalim Purwanto mengemukakan ada Tiga macam kepengikutan, yaitu:

1. Kepengikutan karena naluri dan nafsu.

2. Kepengikutan karena tradisi dan adat.

3. Kepengikutan karena agama dan budi nurani. Kepengikutan karena peraturan hukum. ${ }^{22}$

\section{Sanksi-sanksi yang ada di tangan pemimpin.}

Kekuatan-kekuatan yang ada dibelakang pemimpin menentukan sikap dan tingkah lakunya. Sikap atau reaksi anggota kelompok dari seorang pemimpin yang mempunyai wewenang penuh akan lain jika dibandingkan dengan seorang pemimpin yang kurang atau tidak berwenang. Seorang guru yang baru dibentuk sebagai pejabat pimpinan Sekolah akan bertindak dan berperilaku lain dengan seorang Kepala Sekolah yang telah resmi diangkat dengan surat keputusan dari atasan. Hal ini dapat dikatakan bahwa tinggi rendahnya tingkat kekuasaan dan atau perangkat perundang-undangan menentukan

${ }^{21}$ Purwanto, M. Ngalim. 1993. Administrasi Dan Supervisi Pendidikan. Bandung : PT. Remaja Rosdakarya, hlm. 53

${ }^{22}$ Purwanto, M. Ngalim. 1993. Administrasi Dan Supervisi Pendidikan....., hlm. 53

M. Ma'ruf | 54 
tinggi rendahnya kekuatan atau sangsi seorang pemimpin yang diangkat oleh penguasa atau berdasarkan perundangan tersebut.

\section{Kualitas Pendidikan}

Pendidikan, dari segi kehidupan kultur umat manusia tidak lain adalah sebagai salah satu alat pembudayaan masyarakat manusia itu sendiri. Sebagai suatu alat pendidikan dapat difungsikan untuk mengarahkan perkembangan dan pertumbuhan hidup manusia.Sebagai makhluk pribadi dan juga makhluk sosial kepada titik optimal kemampuan untuk memperoleh kesejahteraan hidup dunia maupun akhirat.Untuk itulah maka pendidikan harus benarbenar memiliki kualitas bagi manusia.

Adapun hal-hal yang dilakukan untuk meningkatkan kualitas pendidikan antara lain :

a. Peningkatan Profesionalisme Guru

b. Peningkatan Materi

c. Peningkatan Pemakaian Metode

d. Peningkatan Sarana

e. Membangkitkan Motivasi Belajar

7. Peran Kepala Sekolah Dalam Meningkatkan Kualitas Pendidikan

Kepala Sekolah sebagai yang bertanggung jawab di Sekolah mempunyai kewajiban menjalankan Sekolahnya. la selalu berusaha agar segala sesuatu di Sekolahnya dapat berjalan lancar. Dengan kata lain Kepala Sekolah harus berusaha agar semua potensi yang ada di Sekolahnya dapat dimanfaatkan sebaik-baiknya dan agar tujuan Sekolah dapat dicapai dengan sebaik-baiknya pula. Oleh sebab itu untuk memenuhi kebutuhan tersebut tak lepas dari peran Kepala Sekolah sebagai pengelola dalam lembaga pendidikan. Adapun yang dimaksud dengan peran Kepala Sekolah dalam meningkatkan kualitas pendidikan di sini adalah usaha-usaha yang dilakukan Kepala Sekolah untuk mencapai kemajuan dan kesempurnaan pendidikan yang dipercayakan kepadanya. Berikut ini penulis akan uraikan tentang peran Kepala Sekolah dalam meningkatkan kualitas pendidikan, yaitu: ${ }^{23}$

${ }^{23}$ Daryanto, H.M. 2001. Administrasi Pendidikan. Jakarta: Rineka Cipta, hlm. 98

$55 \mid$ Kepemimpinan Kepala Sekolah Dalam Meningkatkan Kualitas

PendidikanDi Smp Islam Darul Karomah Mandaranrejo Pasuruan 
1. Kepala Sekolah sebagai Administrator.

Kepala Sekolah sebagai administrator pendidikan bertanggung jawab terhadap kelancaran pelaksanaan pendidikan dan pengajaran di Sekolahnya. Oleh karena itu, untuk dapat melaksanakan tugasnya dengan baik, Kepala Sekolah hendaknya memahami, menguasai dan mampu melaksanakan kegiatan-kegiatan yang berkenaan dengan fungsinya sebagai administrator pendidikan. Adapun dalam setiap kegiatan administrasi ini, di dalamnya mengandung fungsi-fungsi perencanaan, pengorganisasian, pengkoordinasian, pengawasan, kepegawaiaan dan pembiayaan. Oleh karena itu, Kepala Sekolah sebagai administrator hendaknya mampu mengaplikasikan fungsi-fungsi tersebut kedalam pengelolaan Sekolah yang dipimpinnya. ${ }^{24}$

Sehubungan dengan hal diatas, maka tugas Kepala Sekolah dalam bidang administrasi ini dapat digolongkan menjadi 6 bidang manajemen, sebagai berikut :

a. Pengelolaan pengajaran

b. Pengelolaan kepegawaian

c. Pengelolaan kemuridan

d. Pengelolaan gedung dan halaman

e. Pengelolaan keuangan

f. Pengelolaan hubungan sekolah dan masyarakat. ${ }^{25}$

2. Kepala Sekolah sebagai Supervisor

Kepala Sekolah sebagai orang yang bertanggungjawab di Sekolah mempunyai kewajiban untuk menjalankan Sekolahnya, terutama membantu perkembangan anggota-anggota stafnya dalam usaha meningkatkan kualitas pendidikan di Sekolahnya. Untuk mengetahui tanggungjawab tersebut, sebelumnya perlu diketahui lebih dahulu pengertian supervisi. Sebagaimana yang dikemukakan oleh Drs.H.M.Daryanto, bahwasanya Supervisi adalah aktivitas menentukan kondisi atau syarat-syarat yang esensial yang akan menjamin tercapainya tujuan pendidikan. ${ }^{26}$

Melihat definisi diatas, dapat dikatakan bahwasanya Kepala Sekolah sebagai supervisor harus dapat meneliti, mencari dan

${ }^{24} \mathrm{ibid}$
${ }^{25} \mathrm{ibid}$
${ }^{26} \mathrm{ibid}$

M. Ma'ruf | 56 
menentukan syarat-syarat mana yang telah ada dan mencukupi mana yang belum ada atau kurang mencukupi yang perlu diusahakan dan dipenuhi.Disamping itu, Kepala Sekolah juga harus berusaha agar semua potensi yang ada di Sekolahnya, baik potensi yang ada pada unsur manusia maupun yang ada pada alat, perlengkapan, keuangan dan sebagainya dapat dimanfaatkan dengan sebaik-baiknya.

Adapun rumusan-rumusan tentang tugas-tugas Kepala Sekolah sebagai supervisor, sebagaimana yang di kemukakan oleh M.Rifai adalah sebagai berikut :

a. Membantu stafnya menyusun program

b. Membantu stafnya mempertinggi kecakapan dan keterampilan mengajar.

c. Mengadakan evaluasi secara kontinyu tentang kesanggupan stafnya dan tentang kemajuan program pendidikan pada umumnya.

Hal ini bisa dilakukan Kepala Sekolah dengan mengadakan evaluasi data mengenai kunjungan kelas, menyusun rencana evaluasi untuk tiap masa tahun ajaran, mengadakan pertemuan dengan stafnya baik secara perorangan atau dengan seluruh staf untuk membicarakan bersama hasil-hasil pengumpulan data secara evaluatif, atau bisa juga dengan membantu para anggota stafnya untuk mengadakan "self-evaluation" yaitu usaha mengevaluasi diri sendiri. ${ }^{27}$

Dengan demikian dapat ditegaskan bahwa kualitas pendidikan di Sekolah itu terletak pada kualitas yang dimiliki oleh seorang Kepala Sekolah dalam membawa staf-stafnya dalam mengkoordinir dan bertanggungjawab secara penuh terhadap tugas-tugas yang telah ditetapkan. Peran Kepala Sekolah, baik itu sebagai administrator ataupun supervisor akan selalu menjadi ukuran terhadap upaya peningkatan kualitas pendidikan di Sekolah yang dipimpinnya.

\section{METODE PENELITIAN}

\section{Pendekatan dan Jenis Penelitian}

${ }^{27}$ Rifa'i, M.Moh. 1986. Administrasi Pendidikan. Bandung: Jenmars, hlm. 42

57| Kepemimpinan Kepala Sekolah Dalam Meningkatkan Kualitas

PendidikanDi Smp Islam Darul Karomah Mandaranrejo Pasuruan 
Penelitian ini menggunakan jenis penelitian kualitatif yaitu data yang berasal dari naskah wawancara, catatan lapangan, dokumentasi pribadi, catatan memo, dan dokumen resmi lainnya. ${ }^{28}$ Jenis penelitian yang digunakan adalah studi kasus . penelitian ini menggunakan studi kasus tunggal (single-case study) menurut K. Yin yang mana hanya menempatkan sebuah kasus sebagai fokus penelitian, maka akan digali secara mendalam informasi yang berkaitan dengan fokus penelitian di SMP Islam Darul Karomah Mandaranrejo Pasuruan. Sehingga akan ditemukan kesimpulan tentang model kepemimpinan sekolah yang ideal dalam meningkatkan kualitas pendidikan di era globalisasi sekarang.

\section{Data dan Sumber Data Penelitian}

Data adalah informasi yang dikatakan oleh manusia yang menjadi subjek penelitian, hasil observasi, fakta, dokumen yang sesuai dengan fokus penelitian. Informasi dari subjek penelitian dapat diperoleh secara verbal melalui wawancara atau dalam bentuk tertulis melalui analisis dokumen. ${ }^{29}$ Sedangkan sumber data adalah subjek dimana data diperoleh. ${ }^{30}$ Menurut Lofland dalam Lexy J. Moleong mengungkapkan bahwa sumber data utama dalam penelitian kualitatif adalah kata-kata atau tindakan, selebihnya adalah tambahan berupa dokumen dan lain-lain. ${ }^{31}$ Oleh karena itu, jenis data yang terkait dengan penelitian ini ada dua macam yaitu:

a. Data Primer (utama)

Data primer adalah data yang diperoleh secara langsung dari sumber pertama yakni prilaku warga masyarakat melalui penelitian di lapangan. ${ }^{32}$ Adapun sumber data dalam penelitian ini secara spesifik adalah sebagai berikut:

28 Lexy J Moleong, Metodologi Penelitian Kualitatif, (Bandung: PT. Remaja Rosdakarya, 2006), hlm. 5

${ }^{29}$ Ahmadi, Rulam. 2005. Memahami Metodologi Penelitian Kualitatif. Malang: UIN Malang-Press, hlm. 63

30 Arikunto, Suharsimi. 2006. Prosedur Penelitian, Suatu Pendekatan Dan Praktis. Bandung: Rosdakarya, hlm. 79

${ }^{31}$ Lexy J Moleong, Metodologi Penelitian Kualitatif,..., hlm. 157

${ }^{32}$ Suharsimi Arikunto, Prosedur Penelitian, Suatu Pendekatan Dan Praktis...., hlm. 107

M. Ma'ruf | 58 
1) Kepala sekolah SMP Islam Darul Karomah Mandaranrejo Pasuruan yaitu H. Suradji, S.Ag sebagai pimpinan lembaga SMP Islam Darul Karomah.

2) Wakil kepala sekolah bidang kurikulum, wakil kepala sekolah bidang kesiswaan, wakil kepala sekolah bidang sarana \& prasarana serta guru di SMP Islam Darul Karomah.

b. Data Sekunder (tambahan)

Data sekunder adalah data yang diperoleh dari dokumendokumen resmi, buku-buku, hasil penelitian yang berwujud laporan, buku harian, dan sebagainya. Sumber data sekunder yaitu sumber data diluar kata-kata dan tindakan yakni sumber data tertulis.

\section{Teknik Pengumpulan Data}

Teknik pengumpulan data merupakan salah satu hal yang sangat penting bagi sebuah penelitian, sehingga data yang diperoleh benar-benar sesuai dengan judul yang ditentukan. Seperti yang diungkapkan oleh Sugiyono bahwa teknik pengumpulan data dapat dilakukan dengan observasi (pengamatan), wawancara (interview), kuesioner (angket), dokumentasi dan gabungan dari keempatnya. ${ }^{33}$ Untuk mengecek kevalidan dari ketiga teknik tersebut maka dilakukan trianggulasi.

\section{TEMUAN PENELITIAN}

\section{Tipe Kepemimpinan Kepala Sekolah SMP Islam Darul Karomah}

Terdapat beberapa tipe kepemimpinan yang diterapkan kepala sekolah SMP Islam Darul Karomah diantaranya demokrasi danotokrasi karena setiap mengambil keputusan selalu mengutamakan musyawarah untuk mencapai mufakat dan terkadang di waktu terdesak kepala sekolah mengambil keputusan dengan sikap otoriter agar semua urusan bias berjalan dengan baik.

Hal ini sesuai dengan pendapat Hendyat Soetopo dan Wasty Sumanto yang mengatakan bahwa tipe kepemimpinan itu meliputi otoriter, laisez faire, demokratis dan pseudo demokratis. Sementaraitumenurut M. Ngalim Purwanto dan sutadji djojopranoto

\footnotetext{
${ }^{33}$ Sugiyono. 2005. Memahami Penelitian Kualitatif. Bandung: CV. Alfabeta. hlm. 6263

59|Kepemimpinan Kepala Sekolah Dalam Meningkatkan Kualitas

PendidikanDi Smp Islam Darul Karomah Mandaranrejo Pasuruan
} 
menyebutkan bahwa tipe kepemimpinan meliputi tiga hal yaitu otokratis, laisez faire dan demokratis. ${ }^{34}$

Tipe kepemimpinan kepala sekolah yang diterapkan di SMP Islam Darul Karomah sesuai dengan hasil penelitian ialah :

a) Kepemimpinan demokratis adalah kepemimpinan yang aktif ,dinamis, dan terarah yang berusaha memanfaatkan setiap orang untuk kepentingan kemajuan dan perkembangan organisasi. Saransaran, pendapat-pendapat dan kritik-kritik setiap anggota disalurkan dengan sebaik-baiknya dan diusahakan memanfaatkannya bagi pertumbuhan dan kemajuan organisasi sebagai perwujudan tanggung jawab bersama. Tipe kepemimpinan demokratis ini memang paling sesuai dengan konsep Islam Yang mana di dalamnya banyak menekankan prinsip musyawarah untuk mufakat. Hal ini sebagaimana terdapat dalam surah Ali-'Imron ayat 159, yang berbunyi:
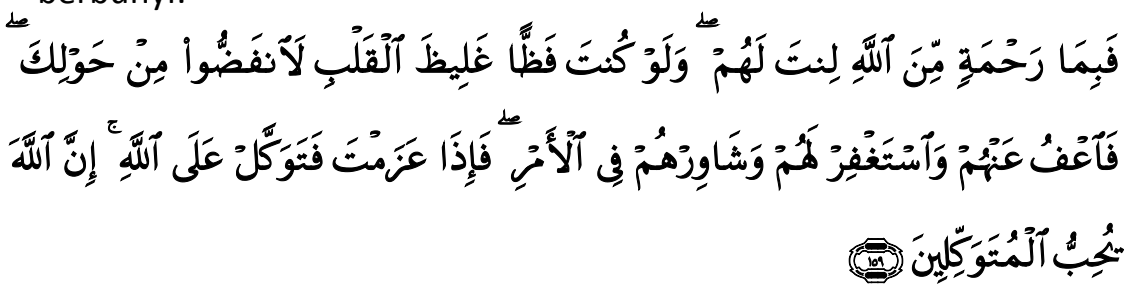

Artinya: "Maka disebabkan rahmat dari Allah-lah kamu Berlaku lemah lembut terhadap mereka. Sekiranya kamu bersikap keras lagi berhati kasar, tentulah mereka menjauhkan diri dari sekelilingmu. karena itu ma'afkanlah mereka, mohonkanlah ampun bagi mereka, dan bermusyawaratlah dengan mereka dalam urusan itu. kemudian apabila kamu telah membulatkan tekad, Maka bertawakkallah kepada Allah. Sesungguhnya Allah menyukai orang-orang yang bertawakkal kepada-Nya" (Q.S. Ali-'Imron (2): 159)

Adapun bukti - bukti kepala sekolah itu menerapkan demokratis adalah kepala sekolah selalu mengadakan musyawarah setiap mau membuat kebijakan contohnya seperti penerapan kurikulum KTSP dan K 13, pembagian jam pelajaran, dan transparasi dalam keuangan

\footnotetext{
${ }^{34}$ Soemanto, Wasty dan Soetopo, Hendyat. 1984. Kepemimpinan Dan Supervisi Pendidikan. Jakarta : PT. Bina Aksara, hlm. 284
} 
b) Tipe Otokratis

Otokratis berasal dari kata oto yang berarti sendiri, dan kratos yang berarti pemerintah.. Jadi otokratis berarti mempunyai sifat memerintah dan menentukan sendiri. ${ }^{35}$

Adapun ciri-ciri dari pemimpin otokratis itu antara lain:

1. Menganggap organisasi sebagai pemilik pribadi.

2. Mengidentikkantujuanpribadidengantujuanorganisasi.

3. Menganggapbawahansebagaialatsemata mata.

4. Tidakmaumenerimakritik, saran, danpendapat.

5. Terlalu tergantung pada kekuasaan formalnya.

6. Dalam tindakan penggerakannya sering mempergunakan approach yang mengandung unsur paksaan dan punitif (bersifat menghukum). ${ }^{36}$

Akibat dari kepemimpinannya tersebut, guru menjadi orang yang penurut dan tidak mampu berinisiatif serta takut untuk mengambil keputusan, guru dan murid dipaksa bekerja keras dengan diliputi perasaan takut akan ancaman hukuman, serta sekolah akan menjadi statis.

Adapun bukti - bukti kepala sekolah menerapkan tipe demokratis adalah ketika ada guru yang sering tidak masuk kelas, ketika mendapatkan bantuan dan ketika ada masalah ke pemerintahan

Jadi tipe kepemimpinan kepala sekolah SMP Islam Darul Karomah menerapkan sistem demokrasi dan otokrasi.

\section{Upaya Kepala Sekolah dalam Meningkatkan Kualitas Pendidikan}

adapun upaya kepala sekolah yang selama ini telah dilakukan dalam rangka meningkatkan kualitas pendidikan di SMP Islam Darul Karomah, antara lain:

a) Mengadakan Fulday school

Fullday School adalah sekolah yang sistem pembelajarannya dilakukan hampir seharian penuh, yaitu yang dimulai dari pagi hingga sore. adapun Fullday School yang diterapkan di SMP Islam Darul Karomah ini yaitu di mula dari pukul 06.45 sampai pukul 15.15 Fullday School

\footnotetext{
${ }^{35}$ Rifa'i, M.Moh. 1986. Administrasi Pendidikan. Bandung. Jenmars, hlm. 38

${ }^{36}$ Rifa'i, M.Moh. 1986. Administrasi Pendidikan..., hlm. 38

$61 \mid$ Kepemimpinan Kepala Sekolah Dalam Meningkatkan Kualitas

PendidikanDi Smp Islam Darul Karomah Mandaranrejo Pasuruan
} 
yang ada di SMP Islam Darul Karomah ini sudah berjalan selama 2 tahun dan diperuntukkan bagi semua siswa siswi kelas IX. Akan tetapi masih dilaksanakan pada hari Senin sampai Rabu saja. Mudahmudahan untuk kedepannya bisa dilaksanakan kesemuajenjangdari hari senin sampai Sabtu.

b) Mengadakan program remedial

Program remedial yang ada di SMP Islam Darul Karomah ini adalah di peruntukkan bagi siswa-siswi kelas VII dan VIII yang tertinggal dalam mata pelajaran tertentu. Siswa-siswi tersebut lalu dikelompokkan sesuai dengan kemampuan yang dimiliki oleh masing-masing anak, baru kemudian di beri pembelajaran khusus yang materinya tidak sama dengan yang diajarkan di kelas. Selama ini program remedial khusus yang ada di SMP Islam Darul Karomah ini masih diperuntukan bagi mereka yang ketinggalan dalam mata pelajaran IPA, Bhs Inggris dan IPS saja. Dan mudah-mudahan untuk tahun ajaran berikutnya bisa diterapkan disemua mata pelajaran baik itu pelajaran umum maupun agama. Sehingga kualitas Pendidikan di SMP Islam Darul Karomah ini bisa mengalami peningkatan secara terus menerus.

c) Membangun gedung tingkat dua

Adapun bangunan gedung yang ada di SMP Islam Darul Karomah, selama kepemimpinan. H. Suradji, S.Ag telah banyak mengalami peningkatan. Gedung yang semula hanya satu Ruang, sekarang telah berubah menjadi 3Ruang. Akan tetapi semua itu telah banyak berpengaruh pada kualitas pendidikan yang ada di SMP Islam Darul Karomah yang selama ini telah mengalami peningkatan yang cukup baik.

d) Membuatlapanganvolley

Semenjak kepemimpinan H. Suradji, S.Ag di SMP Islam Darul Karomah ini, banyak sekali yang telah beliau lakukan demi menunjang kualitas pendidikan di SMP Islam Darul Karomah agar bisa mengalami peningkatan. Salah satu usahanya yaitu dengan membuat lapangan Volly. Lapangan vollyyang ada di SMP Islam Darul Karomah ini terletak di halaman depan gedung Sekolah. Berkat jerih payah ide beliau, akhirnya halaman Sekolah yang dulunya hanya di tumbuhi rumputrumput sekarang bisa dinikmati oleh para siswa ketika melakukan olah raga volly.

e) Menyediakan proyektor 
Proyektor adalah sarana bagi para guru untuk meparkanpelajaran yang selama ini mereka pelajari dengan cara praktek secara langsung. Dengan adanya fasilitas proyektor yang semakin lengkap, maka hasil praktek yang mereka peroleh akan semakin valid. Untuk melaksanakan tanggung jawabnya sebagai Kepala Sekolah, H. Suradji, S.Ag telah mengusahakan untuk menambah jumlah proyektor yang sebelumnnya hanya ada satu proyektor saja. Hal ini telah berdampak pada peningkatan kualitas siswa SMP Islam Darul Karomah.

f) Meningkatkan kualitas guru

Karena guru mempunyai posisi yang penting dalam berlangsungnya Proses Belajar Mengajar (PBM), maka harus ada sebuah ke profesionalan dari seorang guru tersebut dalam melakukan proses belajar mengajar agar tujuan-tujuan pendidikan dapat terealisasi dengan lancar. Sehingga kualitas pendidikan yang ada di Sekolah tersebut dapat mengalami peningkatan.

g) Menambahmatapelajarankhusus

Adapun usaha yang dilakukan oleh Kepala Sekolah untuk lebih meningkatkan kualitas pendidikan yang ada di SMP Islam Darul Karomah yaitu disamping mata pelajaran yang sudah ada seperti Qur'an Hadist, Fiqih, Akidah akhlak, Bahasa Arab, SKI dan lain-lain. Perlu ditambah dengan materi pelajaran khusus seperti seni baca Alqur'an yang diajarkan di kelas VII, pelajaran Qiroatul Kutub yaitu ta'lim muta'allim yang diajarkan pada kelas VIII dan IX, dan pengajian kitab kuning.

h) Pembiasaan sholat berjamaah

Disamping adanya tambahan mata pelajaran khusus, untuk lebih meningkatkan kualitas pendidikan yang ada di SMP Islam Darul Karomah ini juga dilakukan adanya pembiasaan-pembiasaan, seperti pembiasaan membaca Al-Qur'an selama 15 menit setelah bel masuk, pembiasaan melakukan sholat dhuha, pembiasaan sholat dhuhur yang dilakukan secara berjama'ah dengan di bimbing para guru.

Dari uraian di atas diharapkan membentuk generasi penerus yang berkompeten dalam ilmu pengetahuan dan teknologi yang di imbangi dengan iman dan taqwa dalam menghadapi masa yang akan datang. Hal ini sesuai dengan pendapat $M$. Ngalim Purwanto dalam bukunya langeveld yang mengutarakan bahwa tujuan umum pendidikan adalah tujuan yang didalam pendidikan yang seharusnya menjadi tujuan orang

63 | Kepemimpinan Kepala Sekolah Dalam Meningkatkan Kualitas PendidikanDi Smp Islam Darul Karomah Mandaranrejo Pasuruan 
tua dan pendidik yang telah ditetapkan oleh pendidikdan selalu dihubungkan dengan kenyataan yang terdapat pada anak didik itu sendiri. ${ }^{37}$

\section{Peran Kepala Sekolah dalam Meningkatkan Kualitas Pendidikan}

Peran kepala sekolah dalam meningkatkan kualitas pendidikan di SMP Islam Darul Karomah adalah sebagai berikut:

a) Kepalasekolahsebagai administrator

Kepala Sekolah sebagai administrator pendidikan bertanggungjawab terhadap kelancaran pelaksanaan pendidikan dan pengajaran di Sekolahnya. ${ }^{38}$

Sehubungan dengan hal diatas, maka tugas Kepala Sekolah dalam bidang administrasi ini dapat digolongkan menjadi 6 bidang manajemen,yaitu : (1) Pengelolaan pengajaran, (2) Pengelolaan kepegawaian, (3) Pengelolaan kemuridan, (4) Pengelolaan gedung dan halaman, (5) Pengelolaan keuangan, dan (6) Pengelolaan hubungan sekolah dan masyarakat. ${ }^{39}$

b) Kepala sekolah sebagai supervisor

Kepala Sekolah sebagai orang yang bertanggungjawab di Sekolah mempunyai kewajiban untuk menjalankan sekolahnya, terutama membantu perkembangan anggota-anggota stafnya dalam usaha meningkatkan kualitas pendidikan di sekolahnya.

Dapat dikatakan bahwasanya kepala sekolah sebagai supervisor harus dapat meneliti, mencari dan menentukan syarat-syarat mana yang telah ada dan mencukupi mana yang belum ada atau kurang mencukupi yang perlu diusahakan dan dipenuhi. Disampingitu, Kepala Sekolah juga harus berusaha agar semua potensi yang ada di Sekolahnya, baik potensi yang ada pada unsur manusia maupun yang ada pada alat, perlengkapan, keuangan dan sebagainya dapat dimanfaatkan dengan sebaik-baiknya.

Adapun rumusan-rumusan tentang tugas-tugas Kepala Sekolah sebagai supervisor, sebagaimana yang di kemukakan oleh M.Rifai adalah sebagai berikut :

1) Membantu stafnya menyusun program

\footnotetext{
${ }^{37}$ Purwanto, M. Ngalim, dan Djojopranoto, Sutaji.1993. Administrasi Dan Supervisi Pendidikan. Bandung : PT. Remaja Rosdakarya, hlm. 60

${ }^{38}$ Daryanto, H.M. 2001. Administrasi Pendidikan. Jakarta: Rineka Cipta, hlm. 98 ${ }^{39}$ ibid
} 
2) Membantu stafnya mempertinggi kecakapan dan keterampilan mengajar.

3) Mengadakan evaluasi secara kontinyu tentang kesanggupan stafnya dan tentang kemajuan program pendidikan pada umumnya. ${ }^{40}$

Jadi peran kepala sekolah sangat mendukung adanya dalam meningkatkan kualitas pendidikan di SMP Islam Darul Karomah karen amengingat kepala sekolaha dalah pemimpin tertingi di lembaga tersebut maka dari itu peranya sangat betul-betul diharap kan untuk meningkatkan kualitas pendidikan .

\section{E. PENUTUP}

\section{Kesimpulan}

Berdasarkan uraian dan elaborasi antara teori dan temuan lapangan, maka peneliti dapat menyimpulkan beberapa kesimpulan tentang kepemimpinan kepala sekolah dalam meningkatkan kualitas pendidikan yang ada di SMP Islam Darul Karomah sebagai berikut:

a) Dalam menjalankan kepemimpinannya, Kepala Sekolah SMP Islam Darul Karomah sebagian besar menerapkan tipe kepemimpinan demokrasi. Akan tetapi tidak menutup kemungkinan bagi Kepala Sekolah SMP Islam Darul Karomah untuk menjalankan kepemimpinannya dengan menerapkan tipe otokrasi.

b) Usaha Kepala Sekolah dalam meningkatkan kualitas Pendidikan di SMP Islam Darul Karomah antara lain dilakukan usaha-usaha sebagai berikut:

1) Mengadakan Fullday School.

2) Mengadakan program remedial khusus.

3) Membangun gedung tingkat 2.

4) Membuat lapangan Volly.

5) Menyediakan dua Proyektor.

6) Meningkatkan kualitas guru.

7) Menambah mata pelajaran khusus.

8) Pembiasaan sholat berjamaah.

c) Adapun Peran Kepala Sekolah dalam meningkatkan kualitas pendidikan di SMP Islam Darul Karomah meliputi 2 peran, yaitu:

\footnotetext{
${ }^{40}$ Rifa'i, M.Moh. 1986. Administrasi Pendidikan. Bandung. Jenmars, hlm. 38

65|Kepemimpinan Kepala Sekolah Dalam Meningkatkan Kualitas

PendidikanDi Smp Islam Darul Karomah Mandaranrejo Pasuruan
} 
1) Kepala Sekolah sebagai administrator, tugasnya meliputi :
a. Pengelolaan kesiswaan.
b. Pengelolaan kepegawaian
c. Pengelolaan kepengajaran.
d. Pengelolaan keuangan.
e. Pengelolaan sarana dan prasarana.

2) Kepala Sekolah sebagai supervisor, tugasnya meliputi :

a. Membantu stafnya dalam menyusun program.

b. Mempertinggi kecakapan dan ketrampilan mengajar.

c. Mengadakan evaluasi secara kontinyu

b) Saran

Peningkatan kualitas pendidikan bukanlah suatu hal yang mudah untuk diwujudkan. Karena banyaknya faktor-faktor yang mempengaruhinya yang tanpa ada usaha untuk meperhatikan dan mencari solusi, maka usaha peningkatan kualitas pendidikan mustahil akan terwujud. Realitanya, banyak lembaga pendidikan yang dapat tumbuh dan berkembang menjadi lebih baik dan ada pula yang mengalami kemandekan dan bahkan tinggal menunggu kehancurannya. Masalah-maslah dalam pendidikan itu dapat diminimalisir jika kepala sekolah mampu memimpin dan memenej sekolah secara profesional. Dalam kajian ini sedikit memberi gambaran tipe, upaya serta peran kepala sekolah dalam meningkatkan kualitas pendidikan pada lembaga yang dipimpinya. Dari hasil penelitian di lapangan, terdapat beberapa saran sebagai berikut:

a. Bagi lembaga SMP Islam Darul Karomah,

1) Bagi Kepala Sekolah

a) Perlu meningkatkan dan mengembangkan tipe kepemimpinan yang ada, terutama dalam membina hubungan dan kerja sama dengan guru-guru dan staf Sekolah lainnya.

b) Perlu memberikan kebijakan terhadap pemenuhan kebutuhan belajar siswa baik dalam hal sarana dan prasarana maupun keprofesionalan tenaga pengajar di SMP Islam Darul Karomah, juga meningkatkan hubungan yang harmonis dengan bawahan dan orang tua siswa dalam rangka menigkatkan kualitas pendidikan di SMP Islam Darul Karomah

2) Bagi Guru

Diharapkan mampu membimbing dan mengantisipasi belajar siswa dan menerapkan metode pengajaran secara

M. Ma'ruf | 66 
bervariasi sesuai dengan materi yang disampaikan, selalu membantu siswa dalam belajar dan mengatasi kesulitannya serta menjalin kerja sama yang baik dengan guru-guru yang lain guna meningkatkan kualitas pendidikan di sekolah tersebut.

b. Bagi peneliti selanjutnya,

Hasil penelitian ini masih global dan hanya membahas tentang kepemimpinan kepala sekolah dalam lingkup sekolah yang dipimpinnya tanpa meneliti lebih jauh hal-hal yang terkait dengan sosial masyarakat sekitar sekolah. Peneliti selanjutnya diharapkan dapat meneliti lebih jauh bagaimana kepemimpinan dalam masyarakat dalam meningkatkan kesadaran dalam pendidikan.

\section{DAFTAR RUJUKAN}

Ahmadi, Rulam. 2005. Memahami Metodologi Penelitian Kualitatif. Malang: UIN Malang-Press.

Arikunto, Suharsimi. 2006. Prosedur Penelitian, Suatu Pendekatan Dan Praktis. Bandung: Rosdakarya.

Burhanuddin. 1994. Analisis Administrasi Manajemen Dan Kepemimpinan Pendidikan. Jakarta: Bumi Aksara.

Daryanto, H.M. 2001. Administrasi Pendidikan. Jakarta: Rineka Cipta.

Depag RI. Al-Qur'an dan Terjemah. Semarang: Toha Putra.

Dirawat, Lamberi, Busro, Indra Fachrudi, Soekarto.1983. Pengantar Kepemimpinan Pendidikan. Surabaya : Usaha Nasional.

Indar, Djumberansjah. 1992. Ilmu Pendidikan Islam. Malang.: IAIN Sunan Ampel.

Kurtner,Bernard.1989. Bagaimana Menjadi Pemimpin Yang Berhasil. Jakart: PD.Mari Belajar.

Lexy J Moleong. 2006. Metodologi Penelitian Kualitatif. Bandung: PT. Remaja Rosdakarya.

Nawawi, Hadari. 1988. Administrasi Pendidikan. Jakarta : CV Haji Masagung.

67|Kepemimpinan Kepala Sekolah Dalam Meningkatkan Kualitas

PendidikanDi Smp Islam Darul Karomah Mandaranrejo Pasuruan 
NK, Roestiyah. 1982. Masalah-Masalah Ilmu Keguruan. Jakarta : PT.Bina Aksara.

Purwanto, M. Ngalim, dan Djojopranoto, Sutaji. 1991. Administrasi Pendidikan. Jakarta : Mutiara Sumber Wdya.

\section{Administrasi Dan Supervisi Pendidikan.} Bandung : PT. Remaja Rosdakarya.

Rifa'i, M.Moh. 1986. Administrasi Pendidikan. Bandung. Jenmars.

Siagian, Sondang P. 1989. Filsafat Administrasi. Jakarta : CV Haji Masagung.

Soemanto,Wasty dan Soetopo, Hendyat. 1982. Kepemimpinan dalam Pendidikan.Surabaya : Usaha Nasional. 1984. Kepemimpinan Dan Supervisi Pendidikan. Jakarta : PT. Bina Aksara.

Sugiyono.2005. Memahami Penelitian Kualitatif. Bandung: CV. Alfabeta. 